\title{
Landowner Attitudes and Willingness to Accept Compensation from Forest Carbon Offsets: Application of Best-Worst Choice Modeling in Florida USA
}




\section{Introduction}

Forest-based carbon (C) sequestration has been recognized as a cost-effective policy to mitigate global climate change (Lubowski et al., 2006; Alig et al., 2010; Stainback and Alavalapati, 2002). In 2012, forest activities (e.g., Land Use, Land-Use Change, and Forestry) were responsible for sequestering approximately 15 percent $\left(979.3 \mathrm{TgCO}_{2}\right)$ of total United States (U.S.) greenhouse gas emissions (GHG; U.S. Environmental Protection Agency, 2014). Forests account for approximately one-third of all U.S. land area (751 million acres), with much higher proportions in several other states. In Florida, forests cover roughly half (17.3 million acres) of the state (Brown and Nowak, 2010). More than half of this forestland (423 million acres) is owned by individuals, corporations, and other private groups (Smith et al., 2007). Private tenure forest lands in the United States (U.S.) could therefore be enlisted by states in $\mathrm{C}$ offset efforts that meet new state-specific carbon emission reduction goals (EPA CPP Final Rule, 2015).

Using existing $\mathrm{C}$ markets and/or voluntary $\mathrm{C}$ offset programs could both mitigate climate change effects and provide important benefits to forest landowners (Miller et al., 2012). In particular, nonindustrial private forest landowners are a group that could be incentivized to participate in such programs. While private forest landowners in the U.S. are anticipated to play a major role in the implementation of compliance portfolios and carbon accounting programs, little is known about their institutional preferences and willingness to participate in such environmental $\mathrm{C}$ offset markets (e.g., contract length, institutional trust, compensation). Lack of available knowledge on these issues has been cited in the literature as a barrier to participation in similar programs (Butterfield et al., 2005), however a few recent studies have identified several C market features (e.g., payments and penalties) as potentially important to non-industrial private landowners (Dwivedi et al., 2012).

We add to this literature by surveying non-industrial private forest (NIPF) landowners in the state of Florida U.S. on their institutional preferences and potential barriers to participation in C offset programs. In this study we implement a recent innovation in best-worst scaling (BWS), called bestworst choice (BWC), which produces: 1. Measurements of traditional discrete-choice experimentation (DCE) and 2. BWS estimations as well. The use of BWC performs both tasks (BWS and DCE are 
subsets of BWC) by asking respondents to select a best and a worst attribute from an offset program profile (BWS) and to accept or reject an entire scenario (DCE). This approach can better elucidate preferences for and barriers to such programs.

\section{Background}

The use of forest $\mathrm{C}$ markets that pay landowners to capture GHG emissions - for example by planting trees, preventing forest degradation, or improving forest management practices is currently being considered by more than 20 U.S. states, two Canadian provinces, and six Mexican observant regions under three major regional blocks: Western Climate Initiative (WCI), RGGI, and the Midwestern Greenhouse Gas Accord (MGGA). The California Air Resources Board (CARB) is the institution tasked with reducing emissions below 1990 levels by the year 2020 under California's AB32 (California AB 32, 2013). Additionally, the U.S. Environmental Protection Agency's (EPA) announcement of the Clean Power Plant (CPP) rule to cut $32 \%$ of 2005 power plant carbon (C) emissions by the year 2030 is another opportunity for forest landowners (GISTEMP, 2015; EPA CPP Final Rule, 2015). These regional efforts to mitigate GHG are at various stages of implementation, but the CPP is likely to support their development and encourage emulation nationwide.

United States forest landowners currently have four major national options to engage forest carbon markets: CARB, Climate Action Reserve (CAR), American Carbon Registry (ACR), and Voluntary Carbon Standard (VCS). These programs have commitment periods that range from 20 to 100 years and compensation ranging from U.S.\$2.50 to U.S.\$30 per ton of carbon-dioxide equivalent (see Charnley et al., 2010). Risk from intentional or unintentional (e.g., natural disaster) reversals is managed by instituting a series of accountability measures, such as allowing participants to propose insurance products (ACR), carbon buffer pools (ACR, VCS, CAR, CARB), and in some cases, a buyout option (ACR). Buffer tools are used by programs to "pool" or spread the risk of reversals among all registered producers, similar to insurance (American Carbon Registry, 2010). While the CPP proposal and other policies (e.g., AB32, RGGI) have created a state of exceptional policy relevance for forest $\mathrm{C}$ offsets, to date, few studies have explored some of the institutional aspects of carbon markets 
in the U.S. (Peters-Stanley and Daphne, 2013). In a 2007 pilot survey of private landowners in

Massachusetts, Fletcher et al. (2009) used a ratings choice task to examine the likelihood of producing carbon offsets. Participants were surveyed on socioeconomic questions, management activities, reasons for owning land, but also asked to rate alternative carbon credit programs with varying attributes. All options required project verification by a certified professional forester. Their results using a Tobit model indicate that positive ratings increase with expected payment and, surprisingly, commitment length; but decrease with penalty for withdrawal. While this study was limited by its pilot nature, it innovated carbon market research by exploring WTA in the context of different institutional arrangements.

Markowski-Lindsay et al.’s (2011) survey of Massachusetts family forest owners yielded observations of attribute level ratings of carbon sequestration programs including: management plan, contract length, percent of land required to enroll, revenue, additionality, penalty for early withdrawal, and institutional trust (implemented by public or private sector). Results from their random effects ordered probit model found significant preferences for programs with higher net revenue, no withdrawal penalty, shorter contract lengths, and no additional requirements, such as "no requirement that forests must be managed to sequester more carbon than if nothing was done." The researchers also calculated participation probabilities of three types of carbon programs with low, medium, and high participation.

Another Massachusetts study of NIPF landowners surveyed forestland owners using: revenue, contract length, management plan, and penalty for early withdrawal, to construct alternative hypothetical carbon sequestration programs (Dickinson et al., 2012). Results, using ordered logit regression, indicate that respondents prefer programs with lower time commitments and those that do not require a management plan or penalize for early withdrawal. They estimated that $43 \%$ of landowners would participate in a program with: no management plan, a five-year commitment, a $\$ 30$ per-acre annual revenue compensation, and no penalty for early withdrawal.

Elsewhere, a similar survey using the contingent valuation (CV) method with Texas NIPF landowners was used to explore WTA at different levels of contractual duration (Simpson and Li, 
2010). Participants were presented with questions regarding a hypothetical carbon program consisting

of a contract with three different time commitment levels, each with a different annual per-acre compensation, to sell environmental credits, with an option for timber harvesting, as long as it generated additional credits. Factors affecting participation were analyzed using a logit model; and awareness of carbon credits, size of forest landownership, current cost-share participation, and importance of managing forestland for producing income were assessed. Also in the Lake States (Michigan, Wisconsin, and Minnesota), a survey of family forest owners assessed interest in selling C credits (Miller et al., 2012). The study presented participants with carbon market programs with varying revenue and contract duration. The results from this study indicate that approximately $50 \%$ participation would require $\$ 18$ per-acre per-year compensation, and contract length was negatively related to participation.

In general, non-market valuation techniques (e.g., stated preference methods like conjoint analysis and other attribute based tools) typically require participants to rank, choose, or rate particular scenarios of attributes on a given scale (Foster and Mourato, 2002; Elrod et al., 1992; Fletcher et al., 2009). But, a relatively new innovation in scaling methods (best-worst) consists of creating profiles of different attribute levels, and asking participants to choose a "most important" and a "least important" option (Finn and Louviere, 1992; Lusk and Briggeman, 2009; Lusk and Parker, 2009; Campbell and Erdem, 2015). This tool measures the maximum-difference (maxdiff) between attribute-levels under a common utility scale, while offering an alternative approach that overcomes some of the shortcomings of other available methods (e.g., attribute impact measurements that are confounded with level scale values in discrete choice experimentation [Flynn et al., 2007]; and subjective scale measurements resulting from ratings-based methods [Lusk and Briggeman, 2009]). Several other conceptual advances to best, worst, and best-worst choice probabilistic models are being used in applied economics studies (Marely and Louviere, 2005; Lusk and Brooks, 2011; Rigby et al., 2015). The best-worst choice method (Marley et al., 2008), first implemented by Coast et al. (2006) in the field of epidemiology, and applied in this study, is one of these recent innovations to BWS. The BWC method differs from BWS 
in that it asks subjects to perform an additional choice-task of accepting or rejecting the entire scenario of attributes and in doing so also estimate a traditional DCE (Flynn et al., 2007).

More specifically, the two tasks of BWC measure utility differently - directly and indirectly. The first task of BWC, the BWS instruction, measures utility directly by observing attribute level tradeoffs (choose one element, from a profile of attribute levels, that is "best" and one "worst"). The second task (the "accept" or "reject" instruction) is a conjoint choice method, or traditional DCE, that requires survey participants to consider an entire profile of attribute levels (Louviere et al., 2000). Conjoint choice methods infer attribute level utility indirectly by analyzing an outcome measure, such as "accepting" or "rejecting" an entire profile, or choosing one profile from several (Louviere and Islam, 2008). This method produces DCE measurements consistent with traditional demand theory (e.g., willingness-to-accept or pay values; Lusk and Parker, 2009; Aanesen et al., 2015; Oleson et al., 2015). Several studies have shown that BWS and conjoint choice methods produce different measurements of utility (e.g., Louviere and Islam, 2008; Whitty et al., 2014). Thus, BWC has the advantage of producing both BWS direct measurements, as well as estimates consistent with traditional demand theory.

Another contribution of this paper is the use of "risk" as an attribute, which has rarely been addressed in the forest economics and policy literature. Since ACR, VCS, CAR, and CARB currently have options to manage risk using various options such as "risk pools" and/or "insurance," assessing such attributes is timely and policy-relevant. We also note that the range of commitment periods explored the literature is rather limited, and we posit that using more forest management relevant periods such as 5 to 100 years would better simulate market realism (e.g., CARB).

Therefore, the aim of this study is to better understand the institutional preferences and potential barriers for non-industrial private forest landowner participation in $\mathrm{C}$ offset programs. Our first specific objective is to examine barriers to participating in forest $\mathrm{C}$ offset markets using Florida as an example case. The second objective is to implement a recent innovation in best-worst scaling (BWS), called best-worst choice (BWC), which produces measurements of both "traditional" discrete- 
choice experimentation (DCE) and best-worst scaling (BWS). To our knowledge, this is the first BWC study in the field of forest and natural resource economics.

For this study we elicit preferences directly from forest landowners who participate in the Florida Forest Stewardship Program (FSP), which maintains one of the most comprehensive NIPF landowner lists in the Southern U.S. region. This subpopulation of Florida landowners is an ideal representation of private forest managers, for they are highly motivated, well-versed in management practices and barriers, organized into a reliable Extension network, and likely to seriously consider participating in a market for environmental services, like $\mathrm{C}$ sequestration.

\section{Methods}

Survey Design

Studies have typically used a few key attributes to look for evidence of landowner willingnessto-accept (WTA) compensation for producing forest carbon-offsets (Dickinson et al., 2012; Miller et al., 2012). To examine the relative importance and WTA compensation for the institutional attributes we used attributes from these studies (Table 1), but we adapt them to more closely resemble the requirements of available carbon certification programs for Florida landowners (i.e., CAR, VCS, ACR, CARB; Table 2).

Place Table 1 here.

Place Table 2 here.

The survey included experimental questions on four program attributes: contract length (5 to 100 years), annual compensation ( $\$ 5$ to $\$ 30$ per-acre), penalty for early withdrawal (penalty or no penalty), and the type of risk tool (insurance or risk pool), along with demographic and institutional trust questions. Attributes and levels for this study were selected from qualitative research on features of currently available C-offset programs (e.g., CAR, ACR, CARB), similar studies (Fletcher et al., 2009), and nine phone interviews with FSP members in 2011. A similar approach was taken to select demographic and attitudinal questions. 
Although the management plan attribute was used in two previous studies (Markowski-Lindsay et al., 2011; Dickinson et al., 2012), it was not selected for this study because the majority of participants are landowners who already have something akin to this requirement via their participation in FSP. Other contractual requirements such as $100 \%$ of enrolled acreage or specific levels of additionality were not included in this study in favor of emulating existing certification programs (CAR, VCS, ACR, CARB do not require 100\% enrolled acres) and to reduce survey complexity, respectively. The attribute implementer (i.e., governmental or non-governmental carbon offset program) was also explored in this study, but not included in the BWC questions.

To accommodate the variables presented in Table 2 in the most efficient manner (i.e., maximum orthogonal comparison and shortest survey length), we used the orthogonal main effects plan from Street et al. (2005 Table 9 and Figure B-3) to construct this survey and its 16 BWC scenarios. General guidelines from Louviere et al. (2000) for stated preference choice modeling were used to develop the BWC choice tasks. The BWC task consisted of a single profile of attributes with two separate instructions: 1) to select a most preferred and least preferred attribute level, and 2) to consider the profile as a single carbon program and choose whether to enroll or not (see Figure 1). The latter task can be interpreted as a single profile choice model and constrains all attributes to have a represented level in each profile. The choice task consists of presenting survey participants with a bestworst scenario that includes an additional instruction asking if they "Would accept/buy this scenario/good/service" as a whole (e.g., Coast et al., 2006). These two instructions (select a best and worst attribute; accept or reject the entire scenario), allows researchers to: 1) elicit utility comparisons of all attribute levels using the BWS task of BWC; and 2) estimate traditional values of DCE using the binary choice questions of BWC (Flynn et al., 2007). Hence, the BWC method (two instructions) is estimated using both a BWS and a DCE, thus requiring two separate statistical analyses for each of the respective choice-tasks.

Place Figure 1 here. 
We selected demographic and attitudinal questions to help identify landowner characteristics

that may influence willingness-to-accept. These included several key questions from the National Woodland Owners Survey (NWOS; http://www.fia.fs.fed.us/nwos/quest/), which allow comparison of the characteristics of the subpopulation of forest landowners in this study, to those of the most representative statewide forest landowners survey. The NWOS also followed Dillman (2001), and randomly selected a portion (10-20\%) of the full sample of private owners in each state, including forest industry companies, partnerships, tribes, families, and individuals (Butler and Leatherberry, 2004). See Appendix A for a comparison of survey respondent demographics of this study with those of 2002-2006 NWOS survey. Our survey was pre-tested with 24 experts in forestry, policy, and survey design, refined, and electronically implemented following the Dillman method (Dillman et al., 2009).

\section{Econometric Analysis}

We used two different econometric models to estimate each choice task of BWC (Figure 1): a paired estimation approach (conditional logit) to analyze the first task of choosing a "most important" and "least important attribute level (e.g., Flynn et al., 2007; Flynn et al., 2008); and a random effects logit (REL) model to estimate the second task (DCE) of "enrolling" or "not enrolling" in the carboncredit program (e.g., Coast et al., 2006). We use REL to adjust for clustering of individuals' responses and to produce traditional values of DCE (e.g., WTA; Coast et al., 2006). BWS analyses generally fall into two categories: paired estimation, which uses best-worst pairs, and marginal models that use attribute-level observations that are an approximation of the former and may lead to larger standard errors (Flynn et al., 2007). Here, we opt for the paired estimation approach.

\section{Paired estimation of best-worst scaling: BWC First Task}

Paired estimation of the BWS model uses conditional logit analysis to treat each best-worst pair as a unique choice outcome. Namely, each scenario of 4 items (Figure 1), would have $J(J-1)=12$ possible best-worst combinations a person could choose, where $J$ is the number of items per scenario (4 in this case). Following Lusk and Briggeman (2009), if item $j$ is chosen as best and $k$ chosen as 
worst, then $\lambda_{j}$ represents the location of value $j$, for individual $i$, on an underlying scale of importance.

The latent or true level of importance is given by $I_{i j}=\lambda_{j}+\varepsilon_{i j}$, where $\varepsilon_{i j}$ represents the random error term. The same logic applies for item $k$. Thus, given that $j$ was chosen as best and $k$ chosen as worst, these two items represent the maximum difference between all available $J(J-1)$ items on an underlying scale of importance. The probability of individual $i$ choosing $j$ and $k$ is therefore the probability $\left[I_{i j}-\right.$ $\left.I_{i k}>I_{i l}-I_{i m}\right]$, where $I_{i l}$ and $I_{i m}$ are all other $J(J-1)-1$ possible best-worst combinations available in the given scenario. The following multinomial logit (MNL) equation can be applied to this analysis after assuming an i.i.d. type I extreme value distribution on $\varepsilon_{i j}$ :

Equation (1)

$$
\operatorname{Prob}(j \text { is chosen best and } k \text { chosen worst })=\frac{e^{\lambda_{j}-\lambda_{k}}}{\sum_{l=1}^{J} \sum_{m=1}^{J} e^{\lambda_{l}-\lambda_{m}}}
$$

The $\lambda_{j}$ parameters in the equation above were estimated using the conditional MNL command (clogit) with the statistical software package STATA/SE (Flynn et al., 2007). The clogit command is appropriate because it allows for multiple observations from one individual to be grouped together (e.g., Flynn et al., 2007; Flynn et al., 2008; Lusk and Parker, 2009). This adaptation of MNL command requires each scenario (i.e., question) to be expanded into as many outcomes available for each choice, namely, $\mathrm{J}(\mathrm{J}-1)$, where the dependent variable is coded 1 if the best-worst pair was chosen, and 0 otherwise. For example, in this study, each individual provided information for 16 scenarios - each with four attributes that can be picked as best, and four as worst. Each scenario was expanded into $\mathrm{J}(\mathrm{J}-$ 1) $=12$ best-worst pair outcomes (or possible combinations), with chosen best-worst outcomes coded as 1 and the 11 other possible best-worst pairs that were not chosen coded as 0 . The model then records observations that are correlated and affect the error term. In doing so, the clogit model accounts for this correlation among all 16 scenarios for any given individual. Equation 1 was used to estimate the following BWS equation adapted from Flynn et al. (2008):

Equation (2)

$$
U_{\text {diff }}^{i}=\beta_{\text {Att } 1}^{i}+\cdots+\beta_{\text {Att16 }}^{i}+\cdots+\beta_{\text {Att1level } 1}^{i} D_{\text {Att1level } 1}^{i}+\beta_{\text {Att1level } 2}^{i} D_{\text {Att1level } 2}^{i}+\cdots
$$




$$
+\beta_{\text {Att16level } 1}^{i} D_{\text {Att16level } 1}^{i}+\cdots+\varepsilon^{i}
$$

illustrating the relationship between the difference in importance or "utility" ( $U_{\text {diff }}^{i}$ lays on latent utility scale) of each best-worst pair in choice question $i(i=1,2, . ., 12)$, and the 16 (4 attribute impact variable and 12 level scale values) independent variables (Table 2). Each attribute has one impact variable and one level scale value for each level. BWS allows for a separate parameter estimation of the overall average impact of an attribute $\left(\beta_{A t t 1}^{i}\right)$ and the attribute level $\left(\beta_{A t t 1 l e v e l 1}^{i}\right)$ scale value (Flynn et al., 2007). Hence, for choice $i$, the attribute chosen as best has its impact variable ( $\left.D_{\text {Attribute }}^{i}\right)$ taking a value of 1 , and the worst choice impact variable taking a value of -1 , with the rest of the impact variables taking values of 0. Following Flynn et al. (2007), all attributes were also coded using effects coding. Effects coding is an alternative to using dummy codes (dummy variables take 1 if attribute level is present, and zero otherwise). This type of coding makes the attribute levels mean-centered, and the main effect of an attribute can accordingly be defined by L-1 effects-coded variables that represent an arbitrary L-1 number of its levels, where L is the number of levels of an attribute (Luoviere et al., 2000). The L-1 attribute levels can be arbitrarily chosen, and it functions by coding all attribute levels except one (the reference case, or point, used for the common underlying scale; more on this below) with a 0 if absent, 1 if present, and -1 if the base level is present. The base level then corresponds to the negative sum of the estimates of all other levels of the given attribute.

Table 3 provides a description of effects coding for the attribute levels of Table 2. The first column of Table 3 shows the attribute levels (e.g., 4 levels for contract length); the remaining 3 columns (e.g., 3 columns for contract lengths of 10, 40, and 100 years) correspond to their respective effects codes. If the specific attribute has 4 levels, for example, these will be coded in 3 columns with 4 rows - one row for each level and 3 columns for the non-base level attribute levels (the base level is embedded with a -1). It is important to note that the final paired analysis of BWS (Appendix B) included covariate interactions to control for respondent level characteristics (e.g., age, income, education; e.g., Flynn et al., 2008). Since respondent level data does not generally vary for potential best-worst pairs, these covariates were interacted with choice outcomes to provide variation to 
individual characteristics (e.g., Flynn et al., 2008). Accordingly, the model presented in Appendix B was evaluated using interacted-covariates, such as covariate "NGO" ("how important is it to have a non-governmental organization carbon-credit program rather than a governmental carbon-credit program"), multiplied times the choice outcome "Risk Pool." These were found insignificant in most interactions with choice outcomes, and thus excluded from the final model. The inclusion of covariateinteractions increased our independent variables from 16 (without covariate-interactions) to 66 (with covariate-interactions). Although our final sample size yielded 93 completed surveys, concerns for loss of degrees of freedom, given covariate-interactions, are not expected to influence the final model, given that each respondent answered 16 choice-task questions, which resulted in 17,856 choice observations (see Appendix B).

Place Table 3 here.

The resulting orthogonal main effects plan was unbalanced, and therefore not all best-worst pairs were equally available for selection (Street et al., 2005) as these could be a source of potential bias for BWS. Following Flynn et al. (2007) an adjustment was performed with frequency weights using a two-step process, first it divides the number of times each best-worst pair was chosen by the number of times it was available across all scenarios and individuals (availability total). Second, it multiplies this string of numbers by one of the availability totals.

A full model, which included all possible predictor variables, was estimated to identify the attribute with the lowest impact (Time), to omit it from the final model with only significant and/or important variables, and use it as the reference case. These results were estimated on the same latent scale, where Time is the reference point and assigned a 0 value to allow for a more intuitive understanding of the estimates. Given this, a negative sign on a coefficient does not imply a negative relationship with the dependent variable, but rather that it lays to the left (lower value) side of the reference case, under a common underlying scale. 
The dependent variable for the second task (discrete choice) took a 1 if the profile was "accepted" and 0 otherwise. These data were analyzed using random effects logit (REL) to adjust for potentially unobserved individual-specific heterogeneity (e.g., socioeconomic characteristics and contextual effects such as choice task complexity and fatigue; e.g., Coast et al., 2006). This type of unobserved heterogeneity constitutes a violation of DCE statistical assumptions (see Greene, 2003). The REL is appropriate because it assumes that this type of unobserved heterogeneity is independent and part of the error term structure (see Louviere et al., 2000). STATA models REL by assuming that probability of choosing "accept" -or "reject"- is conditional on observations that are assumed to be independently Bernoulli distributed (Rodriguez and Elo, 2003). This model was estimated using multiple specifications of both quantitative and effects-coded independent variables. The attributes "Revenue" and "Time" were quantitatively coded for some models to attain multiple estimations of marginal WTA. All WTA estimates for the binary-choice task (Binary hereafter) are marginal estimates, namely, the ratio of the attribute's marginal effects coefficient to the price coefficient, with units of U.S. dollars per choice.

\section{Results}

We administered the survey to 460 Florida Forest Stewardship Program participants electronically in December 2011, and received a total of 141 responses for a $31 \%$ response rate, consistent with the $20-51 \%$ range of response rates for similar studies (Simpson and Li., 2010; Markowski-Lindsay et al., 2011; Dickinson et al., 2012; Miller et al., 2012). Following Dillman et al. (2009) we assessed potential non-response bias with a telephone survey of $16 \%$ of the nonrespondents. The survey asked non-respondents to indicate the primary reason for not responding, and included three additional questions - two demographic (previous participation in a cost-share program and acres of forestland owned in Florida) and one attitudinal (importance of having a non-government carbon credit program on a 1-5 scale) - for comparison to respondents. Results suggest no significant difference between respondents and non-respondents with respect to the demographic and attitudinal 
questions, and $79 \%$ of non-respondents simply had not received the survey (e.g., due to erroneous email information), suggesting no serious non-response bias issues.

Of 141 responses, 93 were fully completed and included in our predictive modeling. The estimation resulted in two different subset analyses: one, BWS, using paired conditional logit for the first task of BWC; and the other, Binary, using REL for the second task of BWC. The Binary data was also estimated using three distinct model specifications (all using REL) that vary in terms of variable coding: Model 1, Model 2, and Model 3 (Table 4). Model 1 uses effects coding for all independent variables, Model 2 quantitatively codes "Revenue," and Model 3 quantitatively codes "Revenue" and “Time." The last two columns of Table 4 display marginal WTA estimates for Models 2 and 3. Please see Appendix $\mathrm{C}$ for a detailed explanation and summary of the model specifications and coding used in our analyses.

These results are very consistent across models in terms of significance, expected sign, and magnitude. The coefficient of "Insurance" is insignificant, which implies that respondents had no significant preference for either risk pool or insurance. This may be the result of confusion regarding the use of "risk pooling," or simply the fact that participant preferences are driven by some of the other attributes in these hypothetical programs. As anticipated, "Penalty" is negative and significant $(\mathrm{p}<0.05)$ across models. The attribute "No Penalty" elicits the second highest increase in WTA for Model 2 in Table 2. This indicates that the inclusion of "penalty for withdrawal" would require an increase of $\$ 10.14$ acre-per-year in compensation for Model 2 and $\$ 9.00$ in Model 3. Model 1 shows an insignificant $(p>0.1)$ relationship of the lowest level of compensation, but negative and significant $(\mathrm{p}<0.1)$ relationship for $\$ 10$ acre-per-year, and a positive and significant $(\mathrm{p}<0.1)$ for the $\$ 30$ acre-peryear. The lowest level of contract duration, 5 year contract, is insignificant $(p>0.1)$ in both Models 1 and 2 , but a positive and significant $(\mathrm{p}<0.05)$ relationship for a contract duration of 10 years. Contract durations of 40 and 100 years were also significant $(\mathrm{p}<0.05)$, but these had a negative association. The WTA estimates of Model 2 show a similar relationship in terms of sign and magnitude. The inclusion of a 100 -year commitment in a program is estimated to increase $\$ 28.53$ acre-per-year in compensation 
costs. Similarly, the inclusion of a 40-year contract would elicit an increase in compensation costs of $\$ 15.42$, while the use of 10 -year commitment period would decrease compensation costs by $\$ 12.48$. Place Table 4 here.

Table 5 reports landowner WTA compensation to switch between attribute levels, as well as "order of impact" for Binary Model 2. Order of impact is used to compare attribute impacts of various methods of estimating discrete choice experimentation models (Lancsar et al., 2007). The order is determined by the absolute value of column 2, which means that the higher the order of impact, the higher the absolute WTA difference between attribute levels. According to our results, it would require a $\$ 13.11$ acre-per-year compensation to have a landowner switch from a program that has a "40 year contact" to one with 100 years commitment. Participants of a "40 year contact" would give up \$27.90 acre-per-year in compensation to move to a "10 year contract." Moving to a carbon program with "no penalty" for withdrawal would elicit a decrease in compensation cost of $\$ 20.28$ acre-per-year. Figure 2 illustrates the magnitudinal estimates of WTA for Binary Model 2.

Place Table 5 here.

Place Figure 2 here.

The BWS results (Appendix B) indicate that all choice outcomes were significant $(\mathrm{p}<0.10)$. Thirty covariate interactions were significant and eight were not $(p<0.10)$. The type of risk tool was also significant $(\mathrm{p}<0.10)$, which indicates a preference for Risk Pool over Insurance. Revenue was the most important attribute, followed by Risk Tool, which is slightly less important than Penalty for Withdrawal. The attribute Time was the least important. The level scale values (i.e., average effect of an attribute level) indicate preferences similar to those found in the previous Binary models. That is, Penalty (the level scale value) is less important than No Penalty, and the higher levels of Revenue are more important than the lower two. Similarly, the lower two levels (5 and 10 years) of Contract length were also more important than the upper two (40 and 100 years).

Appendix B also indicates that the upper two levels of attribute Revenue are highly significant (at 1\% level), but “\$20 acres-per-year" had a higher importance than “\$30 acres-per-year.” Although 
this relative difference was .07 units of the common utility scale, the relative difference between $\$ 20$

and $\$ 10$ is .85 units. This implies that upper two levels of Revenue are fairly similar in importance. Also, Binary and BWS models agree that the lower two levels of compensation are the least preferred within this attribute. The highest importance among the contract duration attribute was the "5 year contract," and "40 year contract," which was the lowest, followed very closely by "100 year contract."

\section{Discussion}

In this study we implemented a recent innovation in BWC to analyze the preferences of a subpopulation of Florida forest landowners toward different aspects of contemporary carbon markets in the U.S.. Using measurements of marginal WTA compensation, we found that including a penalty for early withdrawal in a carbon offset program would elicit an increase in cost of participation by approximately $\$ 9.00$ to $\$ 10.14$ per-acre per-year. The effect of a program that offers compensation of $\$ 5$ or $\$ 10$ per-acre per-year seems to have a negative or less desirable effect than a program that offers $\$ 20$ or $\$ 30$. Landowners seem to strongly prefer contract durations of 5 to 10 years, while strongly disfavoring a 100-year commitment. Indeed, a program with a 100-year contract would elicit an increase in cost of participation of approximately $\$ 28.53$ acre-per-year, while a 10 -year commitment would lower cost by roughly $\$ 12.48$ acre-per-year. Overall, revenue appears to be the most highly valued aspect of the components of this study, followed by the type of risk tool used to manage uncertainty, which is slightly more valued than having a penalty for early withdrawal. Contract length was the least valued aspect.

The results of this study are consistent with the general findings of attribute influence by other studies (Markowski-Lindsay et al., 2011; Fletcher et al., 2009; Miller et al., 2012; Simpson and Li, 2010). Markowski-Lindsay et al. (2011) found that participants prefer higher net revenue, no penalty for withdrawal, and shorter contractual commitments. The range of the compensation values $(\$ 10$, $\$ 100, \$ 1000$ ) and its emphasis on supply analysis (willingness to participate) of specific carbon-offset programs (amount of required enrolled acreage and whether the program was administered by the public or private sector) did not produce comparable WTA estimates. Their study analyzed the 
probability of participation in three carbon offset program scenarios; "Scenario 1," which includes a

30 -year commitment period, penalty for withdrawal, and $\$ 10$ per-acre per-year compensation, is the only scenario that includes attribute levels similar this study (the other two scenarios included compensations of $\$ 100$ and $\$ 1000$ acres per-year). The participation rates for this scenario were low (between $2 \%$ and $5 \%$ ), which is relatively similar to the results found in our study, which estimated a negative and significant influence of a $\$ 10$ per-acre per-year compensation, and a positive WTA (\$15.42 per-acre per-year) for a 40-year contract. Fletcher et al. (2009) found average participation percentage estimates of $5 \%$ for $\$ 15$ per-acre per-year compensation, $13 \%$ for $\$ 30$, and $33 \%$ for $\$ 50$, which generally agree with the results of our study. Specifically, we also found a negative and significant estimates for compensations that are less than $\$ 20$ per-acre per-year, and positive and significant for $\$ 20$ or $\$ 30$. The Texas study by Simpson and Li (2010) considered contract durations of 1 year, 5 years, and the designation of "conservation easement status." They estimated average WTA of $\$ 15.15$ per-acre per-year for 1 year, $\$ 19.92$ per-acre per-year for 5 years, and $\$ 27.36$ per-acre peryear for conservation easement. Their estimates of WTA for a 5 year contract fall within range of WTA estimates ( $\$ 17.95$ to $\$ 31.47$ per-acre per-year) from our study.

Methodologically, the use of BWC is an important distinction from prior studies on landowner preferences. The BWC method has several advantages over the use of ratings-based methods (Dickinson et al., 2012; Fletcher et al., 2009), or the separate implementation of either BWS and/or DCE. The ratings methods used by Dickinson et al. (2012), Markowski-Lindsay et al. (2011), and Fletcher et al. (2009), are somewhat similar to BWC, in the sense that both are ordinal in nature, but differ significantly in terms of choice task. Those ratings tasks instruct participants to rate each program as a whole, whereas BWC asks respondents to select a best and a worst element (attribute level) of each program, thus allowing analysis at a finer scale. The limitations of ratings-based methods where respondents are not forced to make tradeoffs between attribute levels (i.e., subjective scales) are overcome by BWS choice tasks, which force people to choose a best and worst option, while producing estimates under a common underlying utility scale (Lusk and Briggeman, 2009). 
The addition of the choice task to the BWS has circumvented a major limitation of BWS (Flynn et al., 2007) - its inability to produce an estimate of willingness-to-pay/accept (Louviere and Islam, 2008; Lusk and Parker, 2009). The traditional estimates of WTA and WTP produced by DCE are important in the field of applied economics, and BWC provides a method to take advantage of the BWS model, while producing these value estimates. An additional virtue of BWC is its relatively low burden on respondents. BWC can reduce survey exhaustion by producing BWS and DCE data from a single choice task, thus obviating the use of two separate survey questions to elicit needed information.

\section{Conclusion}

Forests are expected to play a significant role in society's response to climate change, particularly in the heavily forested Southeastern U.S.. However, since most of these forestlands are privately held, landowners will need to be incentivized to do so. Hence, understanding their preferences for various carbon sequestration program features is critical to ensuring their involvement and designing economically effective programs; yet there has been very little published on forest landowner preferences or willingness to accept payments for environmental services.

Here, we presented the results of a survey of non-industrial private forest landowners in Florida, which was used to understand their preferences toward various carbon sequestration program features and levels of payments needed to secure their participation in hypothetical carbon sequestration programs. Extant research has assessed landowner preferences using ranking or discrete choice methods (Markowski-Lindsay et al., 2011; Fletcher et al., 2009; Miller et al., 2012; Simpson and $\mathrm{Li}, 2010$ ). We add to this literature with the use of a relatively novel preference elicitation approach - BWC modeling, which has advantages over ratings-based methods or the separate use of scaling and discrete choice modeling within the same study. Importantly, BWC can produce willingness to accept (WTA) estimates, which are critical for policy assessment (e.g., benefit-cost analysis). It also may help reduce survey exhaustion by allowing researchers to measure importance values and traditional estimates of utility in a single conjoint model. To date there are few publications in the economics literature that employ this approach, and the potential of this method to accurately 
estimate willingness-to-accept (or WTP) and measure attribute impact makes it appealing to applied

researchers. However, there remain several questions for future research related to the use of BWC. For example, more research is warranted on sample size sensitivity, the cognitive effects of the order of choice tasks, and the effects of attribute level position bias. The latter has effect has been assessed in the context of best-worst scaling, but not BWC (Campbell and Erdem, 2015). In addition, validation of this tool using revealed preference data would strengthen the reliability of this method. Further research on this approach within the context of contingent valuation referendum surveys could also test reliability and market realism of this tool for assessing critical environmental issues.

Our findings help add to the sparse literature on forest landowner preferences with respect to payments for ecosystem services. Taken together, this literature suggests that private landowners typically consider carbon sequestration as an ancillary benefit to the production of forest products, and one for which they would actively manage if provided appropriate incentives. Results of our study suggest that landowners' enrollment in such programs is influenced by more than incentive payment levels; the presence or absence of certain program features can heavily influence enrollment decisions. For example, on average Florida landowners would need $+\$ 20.28$ to enroll in a carbon sequestration program with a penalty for withdrawal versus one without such a penalty. Contract length and risk also affect WTA.

Our findings are broadly consistent with other studies in this context, and they can be used to inform policy choices that guide forest management decisions toward more socially desired outcomes. This research is particularly timely given the U.S. EPA's finalization of the CPP rule to reduce power plant carbon emissions by 32\% of 2005 levels by the year 2030 (GISTEMP, 2015; EPA CPP Final Rule, 2015). These results can inform state-level policy decisions that enlist forests to meet statespecific goals. Importantly, the results of this study can be used to inform the development of relevant program guidelines that increase participation in efforts. They can also be used to predict levels of landowner participation given alternative combinations of program features studied here, and thus estimates of private forest contributions to emissions reduction portfolios. 


\section{Acknowledgements}

We thank the Pine Integrated Network: Education, Mitigation, and Adaptation project (PINEMAP); a

Coordinated Agricultural Project funded by the USDA National Institute of Food and Agriculture, Award \#2011-68002-30185 for financial support. We also thank the Florida Forest Stewardship Program for assisting us with the survey implementation.

\section{References}

Aanesen, M., Armstrong, C., Czajkowski, M., Falk-, J., Hanley, N., \& Navrud, S. (2015). Willingness to pay for unfamiliar public goods: Preserving cold-water corals in Norway. Ecological Economics, 112, 53-67.

Alig, R., Latta, G., Adams, D., \& McCarl, B. (2010). Mitigating greenhouse gases: The importance of land base interactions between forests, agriculture, and residential development in the face of changes in bioenergy and carbon prices. Forest Policy and Economics, 12(1), 67-75.

American Carbon Registry (2010). American Carbon Registry Forest Carbon Project, version 2.1. Winrock International, Little Rock, Arkansas.

Brooks, K.R., \& Lusk, J.L. (2011). U.S. consumers attitudes toward farm animal cloning. Appetite 57(2), 483-492.

Brown, M.J., \& Nowak, J. (2012). Florida, 2010 forest inventory and analysis factsheet. U.S. Department of Agriculture Forest Service, Asheville, NC.

Butler, B.J., \& Leatherberry, E.C. (2004). America's family forest owners. Journal of Forestry, 102(7), 4-14.

Butterfield, R., Hansen, E., Fletcher, R., \& Nikinmaa, H. (2005). Forest certification and small forest enterprises: key trends and impacts, benefits and barriers. Washington, DC: Forest Trends.

California AB 32 (2013). Retrieved 11/1/2013 from: http://www.arb.ca.gov/cc/ab32/ab32.htm. 
Campbell, D., \& Erdem, S. (2015). Position bias in best-worst scaling surveys: A case study on trust in institutions. American Journal of Agricultural Economics, 97(2), 526-545.

CARB Final Regulation Order (2014). California Air Resources Board Final Regulation Order. Retrieved 1/10/2015 from: http://www.arb.ca.gov/cc/capandtrade/capandtrade/unofficial_c\&t_082014.pdf.

Charnley, S., Diaz, D., \& Gosnell, H. (2010). Mitigating Climate Change through Small-Scale Forestry in the USA: Opportunities and Challenges. Small-scale Forestry, 9(4):445-462.

Coast, J., Salisbury, C., De Berker, D., Noble, A., Horrocks, S., Peters, T.J., \& Flynn, T.N. (2006). Preferences for aspects of a dermatology consultation. British Journal of Dermatology, 155(2), $387-392$.

Davenport, C. (2015). For States That Don't File Carbon-Cutting Plans, E.P.A. Will Impose 'Model Rule.’ New York Times, Jan. 7. Retrieved 1/12/2015 from: http://www.nytimes.com/2015/01/08/us/politics/for-states-that-dont-file-carbon-cutting-plans-epawill-impose-model-rule-.html.

Dickinson, B.J., Stevens, T.H., Markowski, M., \& Kittredge, D.B. (2012). Estimated participation in U.S. carbon sequestration programs: A study of NIPF landowners in Massachusetts. Journal of Forest Economics, 18(1), 36-46.

Dwivedi, P., Alavalapati, J.R.R., Susaeta, A., \& Stainback, A. (2009). Impact of carbon value on the profitability of slash pine plantations in the southern United States: An integrated life cycle and Faustmann analysis. Canadian Journal of Forest Research, 39(5), 990-1000.

GISTEMP Team (2015). GISS Surface Temperature Analysis (GISTEMP). NASA Goddard Institute for Space Studies. Retrieved 5/13/2015 from: http://data.giss.nasa.gov/gistemp/.

Elrod, T., Louviere, J.J., \& Davey, K.S. (1992). An empirical comparison of ratings-based and choicebased conjoint models. Journal of Marketing Research, 29(3), 368-377. 
Dillman, D.A., Smyth, J.D., \& Christian, L.M. (2009). Internet, Mail, and Mixed-Mode Surveys: The

Tailored Design Method. Hoboken, NJ: John Wiley \& Sons, Inc.

EPA Guidelines (2014). Retrieved 8/15/2014 from:

https://www.federalregister.gov/articles/2014/06/18/2014-13726/carbon-pollution-emissionguidelines-for-existing-stationary-sources-electric-utility-generating\#footnote-108.

EPA CPP Final Rule (2015). Carbon Pollution Emission Guidelines for Existing Stationary

Sources: Electric Utility Generating Units. EPA-HQ-OAR-2013-0602. Retrieved 8/4/2015 from: http://www.epa.gov/airquality/cpp/cpp-final-rule.pdf.

Finn, A., \& Louviere, J.J. (1992). Determining the appropriate response to evidence of public concern: the case of food safety. Journal of Public Policy \& Marketing, 11, 12-25.

Fletcher, L.S., Kittridge, Jr., D., \& Stevens, T. (2009). Forest landowners' willingness to sell carbon credits: A pilot study. Northern Journal of Applied Forestry, 26(1), 35-37.

Flynn, T.N., Louviere, J.J., Peters, T.J., \& Coast, J. (2007). Best-worst scaling: what it can do for health care research and how to do it. Journal of Health Economics 26, 171-89.

Flynn, T., Louviere, J., Peters, T., \& Coast, J. (2008). Estimating preferences for a dermatology consultation using Best-Worst Scaling: Comparison of various methods of analysis. BMC Medical Research Methodology, 8(1), 76-88.

Foster, V., \& Mourato, S. (2002). Testing for consistency in contingent ranking experiments. Journal of environmental Economics and Management, 44(2), 309-328.

Greene, W.H. (2003). Econometric Analysis. 5th ed. Upper Saddle River, NJ: Prentice Hall.

Louviere, J., Hensher, D. \& Swait J. (2000). Stated Choice Methods-Analysis and Application. Cambridge: Cambridge University Press. 
Louviere, J.J., \& Islam, T. (2008). A comparison of importance weights and willingness-to-pay

measures derived from choice-based conjoint, constant sum scales and best-worst scaling. Journal of Business Research, 61(9), 903-911.

Lubowski, R., Plantinga, A., \& Stavins, R. (2006). Land-use change and carbon sinks: econometric estimation of the carbon sequestration supply function. Journal of Environmental Economics and Management, 51, 135-152.

Lusk, J.L. \& Parker, N. (2009). Consumer Preferences for Fat in Ground Beef. Journal of Agricultural and Applied Economics, 41(1), 75-90.

Lusk, J.L., \& Briggeman, B.C. (2009). Food values. American Journal of Agricultural Economics, 91(1), 184-196.

Markowski-Lindsay, M., Stevens, T., Kittredge, D.B., Butler, B.J., Catanzaro, P., \& Dickinson, B.J., (2011). Barriers to Massachusetts forest landowner participation in carbon markets. Ecological Economics, 71, 180-190.

Marley, A. A.J., \& Louviere, J.J. (2005). Some probabilistic models of best, worst, and best-worst choices, 49, 464-480.

Marley, A.A.J., Flynn, T.N., \& Louviere, J.J. (2008). Probabilistic Models of set-dependent and attribute-level best-worst choice. Journal of Mathematical Psychology, 52(5), 281-296.

Miller, K.A., Snyder, S.A., \& Kilgore, M.A. (2012). An assessment of forest landowner interest in selling forest carbon credits in the Lake States, USA. Forest Policy and Economics, 25, 113-122.

Oleson, K. L. L., Barnes, M., Brander, L. M., Oliver, T. a., van Beek, I., Zafindrasilivonona, B., \& van Beukering, P. (2015). Cultural bequest values for ecosystem service flows among indigenous fishers: A discrete choice experiment validated with mixed methods. Ecological Economics, 114.

Peters-Stanley, M. \& Yin, D. (2013). State of the Voluntary Carbon Markets 2013, http://www.foresttrends.org/documents/files/doc_3898.pdf. 
RGGI Auction Results, 2014 http://www.rggi.org/market/co2_auctions/results.

Rigby, D., Burton, M., \& Lusk, J.L. (2015). Journals, Preferences, and Publishing in Agricultural and Environmental Economics. American Journal of Agricultural Economics, 97(2), 490-509.

Rodriguez, G., \& Elo, I. (2003). Intra-class correlation in random-effects models for binary data. The Stata Journal, 3(1), 32-46.

Simpson, H., \& Li, Y. (2010). Environmental Credit marketing Survey Report, Texas Forest Service.

Smith, W.B., Miles, P.D., Perry, C.H., \& Pugh, S.A. (2009). Forest Resources of the United States, 2007. General Technical Report WO-78, U.S. Department of Agriculture Forest Service, Washington Office.

Stainback, G.A. \& Alavalapati, J.R.R. (2002). Economic analysis of slash pine forest carbon sequestration in the southern US. Journal of Forest Economics, 8, 105-117.

Street, D.J., Burgess, L., \& Louviere, J.J. (2005). Quick and easy choice sets: constructing optimal and nearly optimal stated choice experiments, International Journal of Research in Marketing, 22(4), $459-470$.

US Environmental Protection Agency, (2014). Inventory of US Greenhouse Gas Emissions and Sinks: 1990-2012. USEPA \#430-R-14-003. Office of Atmospheric Programs.

Whitty, J. A., Ratcliffe, J., Chen, G., \& Scuffham, P. A. (2014). Australian Public Preferences for the Funding of New Health Technologies A Comparison of Discrete Choice and Profile Case BestWorst Scaling Methods. Medical Decision Making, 0272989X14526640.

Zajac, A. \& Drajem, M. (2014). EPA Coal Plant Emissions Limits Challenged by 12 States. Retrieved 8/20/2014 from: http://www.bloomberg.com/news/2014-08-01/west-virginia-11-other-states-sueepa-over-coal-plant-rule-1-.html. 
(Check one option as the most important and one option as the least important)

\begin{tabular}{|c|c|c|}
\hline $\begin{array}{c}\text { Most } \\
\text { Important }\end{array}$ & Non-Government Carbon-Credit Program & $\begin{array}{c}\text { Least } \\
\text { Important }\end{array}$ \\
\hline$\square$ & Risk Pool & $\square$ \\
\hline$\square$ & No Penalty for Withdrawal & $\square$ \\
\hline$\square$ & \$5 acre-per-year & $\square$ \\
\hline$\square$ & 40 year contract & $\square$ \\
\hline
\end{tabular}

Would you enroll in this program?

$\begin{array}{ll}\text { Yes } & \square \\ \text { No } & \square\end{array}$

Figure 1. Example best-worst choice question. 
Table 1. Empirical studies of willingness-to-participate in hypothetical carbon offset markets in the US.

\begin{tabular}{|c|c|c|c|}
\hline Study & Data & Attributes & Levels \\
\hline \multirow[t]{2}{*}{$\begin{array}{l}\text { Miller et al., } \\
2012\end{array}$} & \multirow[t]{2}{*}{$\begin{array}{l}\text { Lake States family } \\
\text { forest owners }(n=850)\end{array}$} & Revenue & $\begin{array}{l}\$ 3, \$ 5, \$ 10, \$ 20, \$ 30, \$ 40, \$ 50, \\
\$ 60 \text { acre/year }\end{array}$ \\
\hline & & Time & $15,25,40,50$ years \\
\hline \multirow{4}{*}{$\begin{array}{l}\text { Dickinson et al., } \\
2012\end{array}$} & \multirow{4}{*}{$\begin{array}{l}\text { Massachusetts forest } \\
\text { landowners }(n=910)\end{array}$} & Revenue & $\$ 5, \$ 15, \$ 30$ acre/year \\
\hline & & Time & $5,10,15$ years \\
\hline & & Management Plan & Require, Not required \\
\hline & & Withdrawal Penalty & No Penalty, Penalty \\
\hline \multirow{7}{*}{$\begin{array}{l}\text { Markowski- } \\
\text { Lindsay et al., } \\
2011\end{array}$} & \multirow{7}{*}{$\begin{array}{l}\text { Massachusetts family } \\
\text { forest owners } \\
(\mathrm{n}=293)\end{array}$} & Revenue & $\$ 10, \$ 100, \$ 1000$ acre/year \\
\hline & & Management Plan & Require, Not required \\
\hline & & Enrolled acreage & 50 or $100 \%$ \\
\hline & & Time & 15 or 30 years \\
\hline & & Additionality & Required/Not required \\
\hline & & Implementer & Private/Public sector \\
\hline & & Withdrawal Penalty & No penalty, Earnings $+20 \%$ fee \\
\hline \multirow[t]{2}{*}{$\begin{array}{l}\text { Simpson and } \mathrm{Li} \text {, } \\
2010\end{array}$} & \multirow{2}{*}{$\begin{array}{l}\text { Texas non-industrial } \\
\text { private forest } \\
\text { landowners } \\
(n=1,032)\end{array}$} & Time & $\begin{array}{l}\text { 1, 5years, or conservation } \\
\text { easement status }\end{array}$ \\
\hline & & Revenue & $\$ 2$ to $\$ 42$ acre/year \\
\hline \multirow{3}{*}{$\begin{array}{l}\text { Fletcher et al., } \\
2009\end{array}$} & \multirow{3}{*}{$\begin{array}{l}\text { Massachusetts non- } \\
\text { industrial private forest } \\
\text { landowners }(n=17)\end{array}$} & Eligibility & Formal Plan, No Plan \\
\hline & & Revenue & $\$ 5, \$ 15$, or $\$ 30$ acre/year \\
\hline & & Withdrawal Penalty & No Penalty, $\$ 10$ per-acre \\
\hline
\end{tabular}


Table 2. Attributes and levels used to create choice experiment questions.

\begin{tabular}{lll}
\hline Attribute & \multicolumn{1}{c}{ Definition } & Levels \\
\hline Risk Tool & Options for risk reduction in forest project & Insurance \\
& & Risk Pool \\
Penalty & Fines for leaving the program early & No Penalty \\
Time & & Penalty \\
& & 5 -years \\
& & 10 -years \\
Revenue & & 40 -years \\
& & 100 -years \\
& & $\$ 5$ \\
\end{tabular}


Table 3. Description of Effects Coding for Econometric Analysis of Best-Worst Choice Data

\begin{tabular}{lccc}
\hline Attribute & Effects coding & Effects coding & Effects coding \\
\hline Contract length & 10 -years & 40 -years & 100 -years \\
5-years & -1 & -1 & -1 \\
10 -years & 1 & 0 & 0 \\
40-years & 0 & 1 & 0 \\
100-years & 0 & 0 & 1 \\
\hline Revenue & $\$ 10$ & $\$ 20$ & $\$ 30$ \\
\$5 acre-per-year & -1 & -1 & -1 \\
\$10 acre-per-year & 1 & 0 & 0 \\
\$20 acre-per-year & 0 & 1 & 0 \\
\$30 acre-per-year & 0 & 0 & 1 \\
\hline Penalty for early withdrawal & & & - \\
No Penalty & 1 & - & - \\
Penalty & -1 & - & - \\
\hline Risk tool type & & - & \\
Insurance & 1 & - & \\
Risk Pool & -1 & & \\
\hline
\end{tabular}


Table 4. Results from binary choice model: random effects model estimations

\begin{tabular}{|c|c|c|c|c|c|c|}
\hline Attribute & $\begin{array}{l}\text { Model } 1 \\
\text { All effects coded }\end{array}$ & $\begin{array}{l}\text { Model } 2 \\
\text { Revenue quantitative }\end{array}$ & $\begin{array}{l}\text { Model } 3 \\
\text { Revenue \& } \\
\text { quantitative }\end{array}$ & Time & $\begin{array}{l}\text { WTA } \\
\text { Model } 2\end{array}$ & $\begin{array}{l}\text { WTA } \\
\text { Model } 3\end{array}$ \\
\hline Insurance & $0.00(0.08)$ & $0.00(0.08)$ & $-0.05(0.08)$ & & $\$ 0.02$ & $\$ 0.83$ \\
\hline Risk Pool & $0.00^{\mathrm{e}}$ & $0.00^{\mathrm{e}}$ & $0.05^{\mathrm{e}}$ & & $-\$ 0.02$ & $-\$ 0.83$ \\
\hline No Penalty & $0.72 *^{\mathrm{a}}(0.09)^{\mathrm{b}}$ & $0.61 *(0.08)$ & $0.54 *(0.08)$ & & $-\$ 10.14$ & $-\$ 9.00$ \\
\hline Penalty & $-0.72^{\mathrm{e}}$ & $-0.61^{\mathrm{e}}$ & $-0.54^{\mathrm{e}}$ & & $\$ 10.14$ & $\$ 0.50$ \\
\hline Revenue Quantitative & & $0.06^{*}(0.01)$ & $0.06^{*}(0.01)$ & & & \\
\hline Time Quantitative & & & $-0.03 *(0.00)$ & & & $\$ 0.83$ \\
\hline$\$ 5$ acre-per-year & $-0.41^{\mathrm{e}}$ & & & & & \\
\hline$\$ 10$ acre- per-year & $-1.3 *(0.18)$ & & & & & \\
\hline$\$ 20$ acre- per-year & $1.15 *(0.15)$ & & & & & \\
\hline$\$ 30$ acre- per-year & $0.56 *(0.16)$ & & & & & \\
\hline 5 year contract & $2.05^{\mathrm{e}}$ & $1.89^{\mathrm{e}}$ & & & $-\$ 31.47$ & \\
\hline 10 year contract & $0.89 *(0.15)$ & $0.75 *(0.14)$ & & & $-\$ 12.48$ & \\
\hline 40 year contract & $-1.02 *(0.15)$ & $-0.93 *(0.14)$ & & & $\$ 15.42$ & \\
\hline 100 year contract & $-1.92 *(0.18)$ & $-1.71 *(0.16)$ & & & $\$ 28.53$ & \\
\hline Constant & $-0.23 * * *(0.39)$ & $-1.2 *(0.38)$ & $0.2(0.36)$ & & & \\
\hline Number of Respondents & 93 & 93 & 93 & & & \\
\hline Number of Choices & 1552 & 1552 & 1552 & & & \\
\hline Log Likelihood & -609.24 & -639.29 & -669.39 & & & \\
\hline Chi-Square Statistic ${ }^{c}$ & 225.68 & 226.43 & 199.82 & & & \\
\hline
\end{tabular}

${ }^{a}$ One $(*)$, two $(* *)$, and $(* * *)$ asterisk represent $0.01,0.05,0.10$ level of statistical significance, respectively.

${ }^{\mathrm{b}}$ Number in parentheses are standard errors.

${ }^{\mathrm{c}}$ Chi-square statistic associated with a test of the hypothesis that all model parameters are zero.

${ }^{\mathrm{d}}$ Effects coding: negative sum of the above level scale values corresponding to this attribute 
Table 5. Differences in marginal willingness-to-accept (\$/choice) for binary (Model 2) estimates

\begin{tabular}{lllc}
\hline Attribute & $\begin{array}{l}\text { Difference } \\
\text { in WTA }\end{array}$ & $\begin{array}{l}\text { Absolute } \\
\text { value }\end{array}$ & $\begin{array}{l}\text { Order of } \\
\text { impact }\end{array}$ \\
\hline WTA to go from Insurance to Risk Pool & $-\$ 0.04$ & $\$ 0.04$ & 1 \\
WTA to go from No Penalty to Penalty & $\$ 20.28$ & $\$ 20.28$ & 4 \\
WTA to go from a 5 to 10 year contract & $\$ 18.99$ & $\$ 18.99$ & 3 \\
WTA to go from a 10 to 40 year contract & $\$ 27.90$ & $\$ 27.90$ & 5 \\
WTA to go from a 40 to 100 year contract & $\$ 13.11$ & $\$ 13.11$ & 2 \\
\hline
\end{tabular}

